\title{
ANALISIS BOBOT DAN PERINGKAT PORTER UNTUK MENGETAHUI AKTIVITAS YANG PALING BERPENGARUH DALAM RANTAI NILAI MINERAL BIJIH BESI DI INDONESIA
}

\author{
Analysis of Weight and Rating of Porter to Know the Most Influential \\ Activities in the Mineral Chain of Iron Ore in Indonesia
}

\author{
ENDANG MULYANI dan HARTA HARYADI \\ Puslitbang Teknologi Mineral dan Batubara \\ Jalan Jenderal Sudirman 623 Bandung 40211 \\ Telp. (022) 6030483, Fax. (022) 6003373 \\ e-mail: mulyani@tekmira.esdm.go.id
}

\begin{abstract}
ABSTRAK
Indonesia memiliki sumber daya bijih besi yang besar, namun industri domestik yang membutuhkan bahan baku olahan bijih besi masih dipasok impor, karena industri pengolahan bijih besi belum ada. Hal ini menandakan terputusnya rantai nilai dalam industri bijih besi. Tujuan penelitian ini adalah teridentifikasinya rantai nilai yang putus dari industri bijih besi dan berbagai kondisi yang menyebabkan aktivitas-aktivitas yang membentuk rantai nilai produk dari industri bijih besi tidak berjalan. Analisis ini menggunakan metode analisis bobot dan peringkat Porter. Berdasarkan hasil analisis dengan menggunakan metode ini pada aktivitas primer, diketahui aktivitas operasi dan penyediaan insfrastruktur memiliki bobot peringkat tertinggi dengan skor 0,615 dibanding aktivitas lainnya, logistik ke dalam $(0,461)$, logistik ke luar $(0,307)$, penjualan dan promosi $(0,153)$, pelayanan $(0,153)$. Dalam aktivitas sekunder, manajemen sumber daya manusia memiliki bobot tertinggi yang mempengaruhi analisis rantai nilai dengan nilai skor $(0,727)$, dibanding infrastruktur perusahaan sebesar 0,363 , teknologi $(0,545)$, pengadaan $(0,181)$. Aktivitas-aktivitas yang memiliki bobot peringkat tinggi dalam rantai nilai industri bijih besi, mempunyai potensi untuk dikembangkan, sehingga menjadi unggulan bagi perusahaan untuk menghasilkan produk dari bahan baku menjadi produk yang bernilai tambah tinggi. Hasil analisis dapat menjadi masukan bagi pemerintah untuk membuat kebijakan meningkatkan aktivitas primer dan sekunder yang memiliki bobot rendah, sehingga rantai nilai bijih besi dapat berjalan.
\end{abstract}

Kata kunci: rantai nilai, bijih besi, bobot, peringkat, analisis Porter

\begin{abstract}
Indonesia has a large iron ore resource, but domestic industries that require raw materials of iron ore processing are still supplied by imports, because the iron ore processing industry does not yet exist. This marks the value chain break off in the iron ore industry. The purpose of this study is to identify the broken value chain of the iron ore industry and the various conditions that cause the product value chain of the iron ore industry is not running. This analysis uses Porter's weighting and ranking methods. Based on the results of the analysis using this method on the primary activity, it is known that the operational activity and the provision of infrastructure have the highest ranking with the score of 0.615 compared to other activities : logistics in (0.461), logistics out (0.307), sales and promotion (0.153), service (0.153). In secondary activities, human resource management has the highest weights that affect value chain analysis with scores of 0.727 , compared to firm infrastructure (0.363), technology (0.545), procurement (0.181). Activities with high rankings in the value chain of the iron ore industry, have the potential to be developed, making it a pre-eminent company for
\end{abstract}


producing products from raw materials into high value-added products. The results of the analysis can be used as an input for the government to make policies to increase the primary and secondary activities with low weight, so that the value chain of iron ore can works well.

Keywords: Value chain, iron ore, weight, rating, Porter analysis.

\section{PENDAHULUAN}

Indonesia memiliki potensi sumber daya pasir besi dan bijih besi cukup besar, sebagai bahan baku industri baja, dengan jumlah deposit berupa sumberdaya 8.297.110.474 ton dan cadangan sebesar 1.630.,807.240 ton. Sumber daya dan cadangan tersebut memiliki karakteristik yang beragam, baik dari segi kualitas maupun jenis mineral besi yang terkandung di dalamnya serta keberadaannya menyebar secara sporadis. Menurut data Pusat Sumber Daya Geologi (2016), sumberdaya untuk industri besi baja ini dapat diklasifikasikan menjadi tiga jenis, yakni besi laterit, besi primer dan pasir besi. Besi laterit mempunyai sumberdaya sebesar 2.440.455.194 ton dan cadangan 542.514.188 ton yang tersebar di Kalimantan Selatan, Sulawesi Selatan, Sulawesi Tenggara, Maluku Utara dan Papua Barat. Besi primer atau bijih besi magnetithematit dengan sumber daya 1.397.068.930 ton dan cadangan 279.354.825 ton tersebar di Lampung, Sumatera Barat, Jambi, Belitung, Kalimantan Barat, Kalimantan Selatan dan Sulawesi Selatan. Pasir besi dengan jumlah sumber daya sebesar 4.459.586.350 ton dan cadangan sebesar 808.938.227 ton, tersebar di Daerah Istimewa Yogyakarta, Maluku Utara dan Papua.

Menurut Permana (2010), sebelum UndangUndang Nomor 4 Tahun 2009 diberlakukan, kegiatan hulu besi lebih berorientasi ekspor bijih. Setelah undang-undang ini dan Peraturan Menteri Energi dan Sumber Daya Mineral No. 7 Tahun 2012 diberlakukan, pemilik Izin Usaha Pertambangan wajib melakukan proses pengolahan dan/ pemurnian sesuai dengan batasan minimal sebelum menjual produknya ke luar negeri, sehingga produknya memiliki nilai ekonomi yang tinggi dan juga memiliki daya guna yang lebih besar (ada peningkatan nilai tambah ekonomi dan daya guna), serta dapat memasok kebutuhan seluruh industri di dalam negeri yang berbasis besi yang selama ini tergantung pasokan impor. Kebijakan ini tentunya memengaruhi perkembangan proses hilirisasi di dalam negeri. Menurut Kementerian Perindustrian (2016), kegiatan ekonomi besi baja dibangun oleh 45 kegiatan ekonomi, yang terdiri dari 4 jenis pertambangan bijih logam (2 jenis bijih besi, 1 jenis nikel dan 1 jenis pasir krom), dan 41 jenis manufaktur berbasis besi baja dan logam lainnya yang menjadi kegiatan hilirnya. Indonesia sudah memiliki 2 perusahaan pertambangan yang mengolah bijih besi, namun hasilnya belum sepenuhnya bisa digunakan oleh industri besi baja yang merupakan industri hilir bijih besi.

Supaya banyak pengusaha yang mau membangun pabrik pengolahan dan pemurnian besi, berdasarkan data Direktorat Jenderal Mineral dan Batubara (2017), dukungan pemerintah dalam masalah penyediaan bahan baku bijih besi untuk pembangunan industri pengolahan dan pemurnian besi diseluruh wilayah Indonesia disediakan dalam jumlah besar sebanyak 1.487.063 juta ton dan tersebar di 5 pulau atau 21 provinsi, antara lain untuk Sumatera (102.601.759 ton), Jawa (473.247.884 ton), Kalimantan (467.824.244 ton), Sulawesi (76.872.730 ton), dan Sumbawa (366.498.305 ton). Namun sampai tahun 2017, rencana beberapa pabrik pengolahan bijih besi banyak yang tidak terealisasi. Kondisi ini menyebabkan industri di dalam negeri masih tergantung pasokan impor, padahal sumber daya besi yang dimiliki Indonesia sangat besar, dan jumlah bahan baku yang disediakan oleh pemerintahpun lebih dari cukup. Di samping menyebabkan ketergantungan impor, tidak terealisasinya pabrik pengolahan ini menyebabkan Indonesia kehilangan nilai tambah yang tinggi dari industri besi baja, kehilangan devisa negara untuk membeli bahan baku olahan impor,serta rendahnya daya saing di pasar ekspor, karena harga produknya tinggi, dan secara mikro, banyak perusahaan tambang mengalami kerugian yang besar dari investasi yang sudah ditanamkan dalam industri pengolahan dan pemurnian yang berhenti ini. 
Sampai dengan tahun 2017, hampir semua industri pengolahan dan pemurnian besi yang direncanakan berjumlah 7 buah, semuanya tidak berjalan. Ketujuh perusahaan pengolahan dan pemurnian besi tersebut adalah PT. Silo, PT. Sumber Baja Prima, PT. Megatop Inti Selaras, PT. Mikgro Metal Perdana, PT. Rusan Sejahtera, PT. Quantum Energi Perkasa, dan PT. Jogya Magasa Iron; demikian juga 2 industri yang sudah beroperasi dari tahun 2016, yang berada di Kalimantan Selatan, yaitu PT. Delta Prima Steeldi Kabupaten Tanah laut dan PT. Meratus Jaya Iron Steel di Batu Licin, saat ini sudah kesulitan beroperasi.

Berdasarkan data Direktorat Jenderal Mineral dan Batubara (2017), 7 perusahaan berencana membangun smelter besi berupa pig iron dan besi spon dengan kebutuhan bijih/pasir besi 17.490.000 ton/tahun dan jumlah investasi USD 535.370.000. Dari 7 smelter tersebut yang menggunakan bahan baku bijih besi hanya 2 perusahaan, yaitu PT. Silo dan PT. MMP, sedang 5 smelter lainnya berupa pasir besi.

Tujuan penelitian ini adalah teridentifikasinya segala permasalahan yang menyebabkan hampir seluruh industri pengolahan dan pemurnian besi yang berencana membangun pabrik ini tidak berjalan, dengan mengkaji segala aktivitas atau berbagai rangkaian kegiatan yang dilakukan perusahaan yang memengaruhi kondisi perusahaan atau rantai nilai perusahaan industri pengolahan dan pemurnian besi.

\section{METODE}

\section{Langkah-langkah Melakukan Analisis Rantai Nilai (Value Chain Analysis)}

Untuk mendapatkan data primer, kajian ini menggunakan metodologi observasi atau wawancara dengan survei langsung ke perusahaan tambang yang menjadi studi kasus yaitu, PT. Delta Prima Steel dan PT. Meratus Jaya Iron Steel, yang mewakili 9 perusahaan pengolahan dan pemurnian besi yang berhenti beroperasi. Adapun untuk mendapatkan data sekunder, dilakukan melalui studi literatur dari berbagai jurnal, prosiding, skripsi, makalah yang terkait dengan analisis rantai nilai dan dari Direktorat Jenderal Mineral dan Batubara, Pusat Sumber Daya Geologi untuk data pendukung yang terkait dengan kondisi pemasokan dan kebutuhan industri bijih besi. Metode observasi digunakan untuk mendapatkan informasi langsung suatu obyek, suatu kondisi dan suatu sistem perencanaan serta peristiwa yang sedang terjadi yang dihadapi industri pengolahan dan pemurnian. Dari hasil observasi atau wawancara dapat diketahui berbagai faktor rangkaian kegiatan dalam rantai nilai industri pengolahan dan pemurnian yang dihadapi perusahaan, yang menyebabkan dan sekaligus memengaruhi kondisi industri tersebut. Selanjutnya, seluruh rangkaian kegiatan rantai nilai industri ini diformulasikan ke dalam sebuah tabel data, dianalisis dan dapat diketahui penyebab rantai nilai industri ini tidak dapat berjalan dan tidak dapat beroperasi.

Metode yang digunakan dalam analisis rantai nilai bijih besi (studi kasus PT. Delta Prima Steel dan PT. Meratus Jaya Iron Steel) menggunakan model rantai nilai dari Porter. Analisis ini digunakan untuk mengetahui rangkaian aktivitas dari perusahaan industri bijih besi yang menunjukkan aktivitas mana yang sudah optimal dan aktivitas mana yang belum optimal dalam memberikan kontribusi atas keberhasilan rantai nilai industri bijih besi dalam mengolah produk bahan baku bijih besi hingga menjadi produk jadi (Parlinah et al., 2015).

Metode rantai nilai industri bijih besi dari Porter ini digunakan dengan cara memberikan bobot, bobot relatif, nilai dan bobot skor pada setiap aktivitas rantai nilai, baik aktivitas primer maupun sekunder perusahaan dengan peringkat bobot dan nilai dari 1 sampai 4, tergantung kepentingan aktivitas dalam industri tersebut (Tabel 1). Selanjutnya dari perhitungan tersebut dihitung skor dari aktivitas primer dan sekunder dengan mengalikan bobot relatif dengan nilai (Andri, 2013). Penilaian untuk bobot dan nilai dengan peringkat 1 atau lebih sampai peringkat 4 adalah sebagai berikut:

a. Penilaian akan diberi peringkat 1 atau lebih, kalau indikator kinerjanya cukup penting. 
Tabel 1. Rantai nilai perusahaan berdasarkan penilaian Porter

\begin{tabular}{|c|c|c|c|c|}
\hline Aktivitas & Bobot & $\begin{array}{l}\text { Bobot } \\
\text { Relatif }\end{array}$ & Nilai & Skor \\
\hline \multicolumn{5}{|l|}{ Aktivitas Primer : } \\
\hline Logistik ke dalam & ....... & ....... & ........ & ........ \\
\hline Operasi & ........ & ......... & ......... & ......... \\
\hline Logistik ke luar & ....... & $\ldots \ldots$. & ....... & ........ \\
\hline Penjualan dan promosi & ....... & $\ldots \ldots$. & ....... & ....... \\
\hline Pelayanan & ........ & $\ldots \ldots$ & ......... & ......... \\
\hline \multicolumn{5}{|l|}{ Aktivitas Sekunder : } \\
\hline Infrastruktur perusahaan & ....... & $\ldots \ldots$. & ....... & ....... \\
\hline Manajemen Sumber Daya Manusia. & ........ & ........ & ........ & ........ \\
\hline Teknologi & ....... & ....... & ........ & ....... \\
\hline Pengadaan & ........ & $\ldots \ldots$. & ......... & ......... \\
\hline Total & & 1,00 & ........ & $\ldots \ldots .$. \\
\hline
\end{tabular}

b. Penilaian akan diberi peringkat 2 atau lebih, kalau indikator kinerjanya penting.

c. Penilaian akan diberi peringkat 3 atau lebih, kalau indikator kinerjanya sangat penting.

d. Penilaian akan diberi peringkat 4, kalau indikator kinerjanya sangat penting dan memengaruhi rantai nilai.

Menurut Porter (1985), aktivitas primer ataupun sekunder yang memiliki skor tertinggi merupakan aktivitas yang berpotensi menciptakan nilai bagi industri dalam rantai nilai untuk menghasilkan produk yang bernilai tambah, sedangkan aktivitas dengan skor terendah merupakan aktivitas yang perlu diperhatikan, karena masih belum optimal dalam menciptakan nilai tambah dalam rantai nilai perusahaan.

\section{HASIL DAN PEMBAHASAN}

\section{Hasil}

Pada aktivitas primer, aktivitas operasi mempunyai bobot tertinggi yaitu 4 dengan nilai 2, karena masalah finansial ini yang paling memengaruhi berjalannya rantai nilai dari industri bijih besi. Akibat masalah finansial ini perusahaan sulit mengawasi jalannya operasi agar sesuai dengan standar internasional dan sulit melakukan pemantauan penggunaan seluruh mesinmesin pabrik. Aktivitas primer selanjutnya adalah logistik ke dalam dengan bobot 3 dan nilai 2. Perusahaan bergantung kepada pasokan IUP dari perusahaan lain, sehingga kalau ada ganggunan dari perusahaan IUP maka akan mengganggu operasi produksi perusahaan.

Pada aktivitas sekunder yang memiliki bobot tertinggi adalah manajemen sumber daya manusia (SDM), dengan bobot 4 dan nilai 2, karena SDM ini sangat penting dan memengaruhi berjalannya rantai nilai industri bijih besi dan aktivitas yang berpotensi menciptakan nilai bagi industri. Aktivitas selanjutnya adalah teknologi dengan bobot 3 dan nilai 2, karena dengan teknologi ini dapat menghasilkan produk yang bermutu tinggi, melakukan peningkatan inovasi dan modernisasi terhadap hasil produknya.

Berdasarkan hasil yang diperoleh melalui analisis rantai nilai pada industri bijih besi dengan menggunakan analisis bobot dan peringkat (Tabel 2) pada aktivitas primer, maka aktivitas operasi dan penyediaan insfrastruktur memiliki bobot peringkat tertinggi dengan skor 0,615 dibanding aktivitas lainnya. Berarti aktivitas ini sangat berpengaruh terhadap berjalannya rantai nilai pasir besi dan bijih besi, sedangkan aktivitas primer yang memengaruhi rantai nilai selanjutnya adalah logistik kedalam dengan skor 0,461, logistik ke luar dengan skor 0,307 , penjualan dan promosi dengan skor 0,153 , pelayanan dengan skor 0,153.

Dalam aktivitas sekunder, manajemen sumber daya manusia memiliki bobot tertinggi yang memengaruhi analisis rantai nilai dengan skor 0,727 , dibanding infrastruktur perusahaan dengan skor 0,363, 
teknologi dengan skor 0,545, pengadaan dengan skor 0,181. Aktivitas-aktivitas yang memiliki bobot peringkat tinggi dalam rantai nilai industri bijih besi, mempunyai potensi untuk dikembangkan, sehingga menjadi unggulan bagi perusahaan untuk menghasilkan produk dari bahan baku menjadi produk yang bernilai tambah tinggi. Hasil analisis menjadi masukan bagi pemerintah untuk membuat kebijakan meningkatkan aktivitas primer dan sekunder yang memiliki bobot rendah, sehingga rantai nilai bijih besi dapat berjalan.

Tabel 2. Hasil perhitungan rantai nilai mineral pasir besi dan bijih besi berdasarkan bobot dan peringkat Porter. Studi Kasus PT. Delta Prima Steel dan PT. Meratus Jaya Iron Steel

\begin{tabular}{|c|c|c|c|c|c|}
\hline & AKTIVITAS & Bobot & $\begin{array}{l}\text { Bobot } \\
\text { Relatif }\end{array}$ & Nilai & Skor \\
\hline AKTIVI & TAS PRIMER : & & & & \\
\hline 1. & Logistik ke dalam & 3 & 0,23077 & 2 & 0,46154 \\
\hline & $\begin{array}{l}\text { i. Perusahaan mengalami kesulitan dalam masalah } \\
\text { pengelolaan sumber-sumber yang terkait dengan } \\
\text { bahan baku, karena bahan baku bijih besi dipasok IUP } \\
\text { dari lain. }\end{array}$ & & & & \\
\hline & $\begin{array}{l}\text { ii. Perusahaan kesulitan dalam mengelola masalah } \\
\text { sumber bahan baku, akibatnya pengadministrasian } \\
\text { perusahaan menjadi terganggu saat bahan baku sulit } \\
\text { diperoleh. }\end{array}$ & & & & \\
\hline 2. & Operasi & 4 & 0,30769 & 2 & 0,61538 \\
\hline & $\begin{array}{l}\text { iii. Selain itu, perusahaan mengalami kesulitan dalam } \\
\text { masalah finansial, sehingga mengakibatkan } \\
\text { pemeliharaan penggunaan seluruh aset perusahaan } \\
\text { sulit untuk dilaksanakan. }\end{array}$ & & & & \\
\hline & $\begin{array}{l}\text { iv. Perusahaan mengalami kesulitan dalam mengawasi } \\
\text { jalannya operasi agar sesuai dengan standar } \\
\text { internasional. }\end{array}$ & & & & \\
\hline & $\begin{array}{l}\text { v. Perusahaan mengalami kesulitan untuk melakukan } \\
\text { pemantauan penggunaan seluruh mesin-mesin pabrik. }\end{array}$ & & & & \\
\hline 3. & Logistik ke luar & 2 & 0,15385 & 2 & 0,30769 \\
\hline & $\begin{array}{l}\text { Perusahaan kesulitan untuk membuat jalur distribusi yang } \\
\text { seimbang antara jaringan pabrik, kantor cabang dengan } \\
\text { kantor pusat secara konvensional dan kesulitan untuk } \\
\text { berhubungan dengan menggunakan teknologi informasi. }\end{array}$ & & & & \\
\hline 4. & Penjualan dan promosi & 2 & 0,15385 & 1 & 0,15385 \\
\hline & $\begin{array}{l}\text { i. Perusahaan memiliki kelemahan dalam penjualan dan } \\
\text { promosi yang menyebabkan tidak tersedianya pusat } \\
\text { informasi yang cukup untuk menyampaikan informasi } \\
\text { bagi konsumen. }\end{array}$ & & & & \\
\hline & $\begin{array}{l}\text { ii. Perusahaan memiliki kelemahan dalam penjualan dan } \\
\text { promosi disebabkan biaya produksi yang tinggi, } \\
\text { sehingga hasil produk-produk kurang inovatif dan } \\
\text { kurang kompetitif. }\end{array}$ & & & & \\
\hline & $\begin{array}{l}\text { iii. Perusahaan, belum sepenuhnya menjalankan } \\
\text { Corporate Social Responsibility (CSR) bagi masyarakat } \\
\text { sekitar tambang. Kegiatan CSR ini tidak bersifat } \\
\text { promosi, namun dapat menambah nilai perusahaan } \\
\text { tambang dimata masyarakat. }\end{array}$ & & & & \\
\hline & $\begin{array}{l}\text { iv. Perusahaan belum memiliki kelengkapan fasilitas dan } \\
\text { layanan hasil produk olahan yang dimbangi dengan } \\
\text { perkembangan teknologi. }\end{array}$ & & & & \\
\hline & $\begin{array}{l}\text { v. Perusahaan belum melakukan penataan lokasi kantor } \\
\text { cabang yang strategis, agar dapat berfungsi lebih efektif } \\
\text { sebagai penyedia produk dan layanan produknya. }\end{array}$ & & & & \\
\hline
\end{tabular}




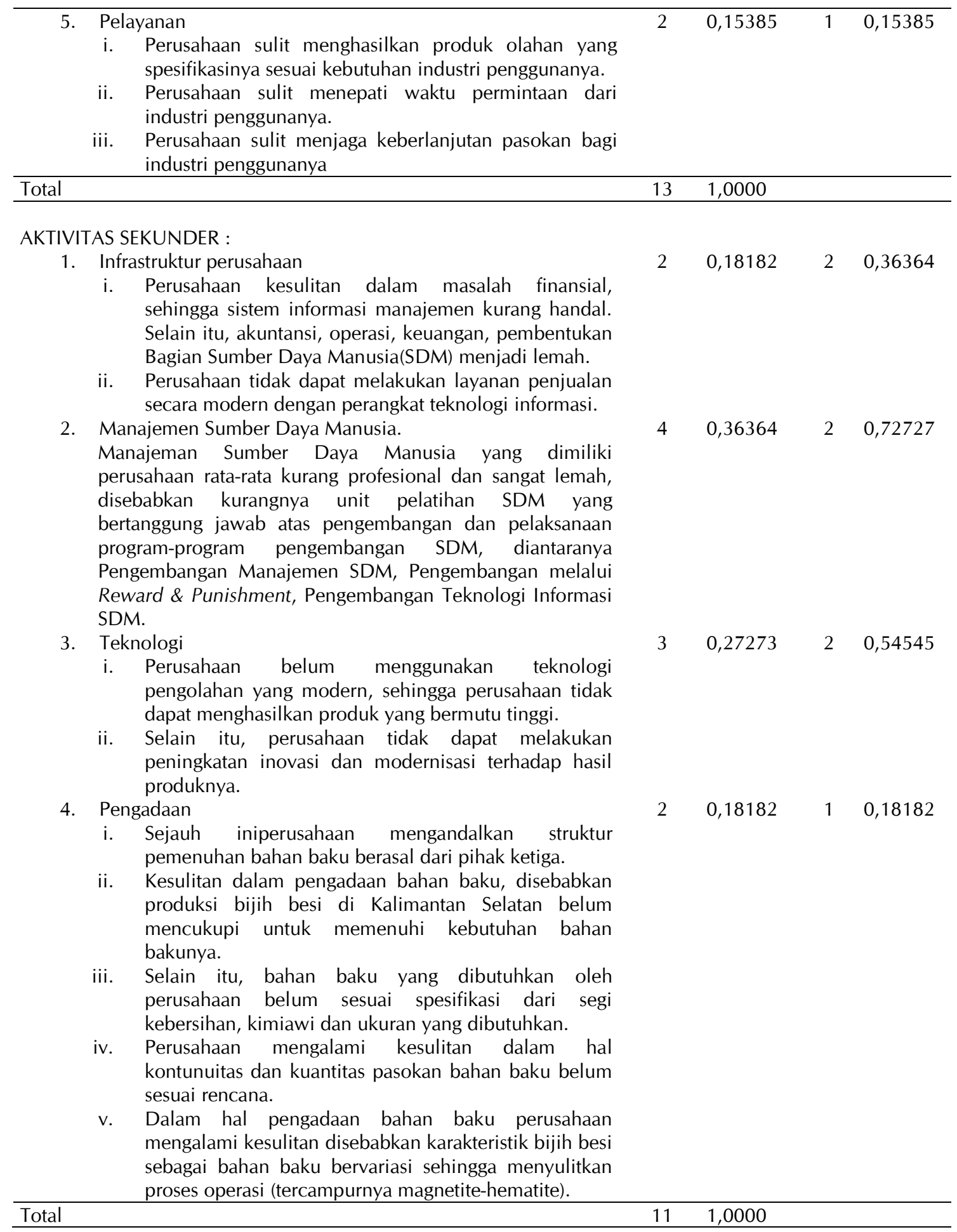

Aktivitas primer pada rantai nilai industri pasir besi dan bijih besi yang memiliki total skor terendah adalah aktivitas primer pada promosi dan pelayanan dengan masing-masing nilai skor sebesar 0,153. Sedangkan pada aktivitas sekunder, yang memiliki nilai skor terendah adalah pada pengadaan dengan skor 0,181 .
Skor nilai terendah ini, perlu mendapat perhatian, karena pada aktivitas ini perusahaan bisa beroperasi untuk menghasilkan produk yang bernilai tambah. Dengan promosi dan pelayanan, produk dapat terjual, dan dengan pengadaan, produk dapat berjalan karena kebutuhan bahan bakunya terpenuhi. Aktivitas 
yang memiliki nilai rendah dalam rantai nilai industri pasir besi dan bijih besi tetap memiliki pengaruh, karena dalam proses rantai nilai yang paling utama adalah proses kesatuan yang saling berpengaruh dalam kinerja perusahaan.

\section{Pembahasan}

Rantai nilai industri bajadari hulu sampai hilir dimulai dari proses hasil tambang berupa pasir besi dan bijih besi (hulu) yang menentukan daya saing industri baja suatu negara, karena merupakan industri pemasok dalam rantai pasokan industri baja (hilir) (PT. Krakatau Steel, 2016). Hasil industri baja (hilir dari pasir besi dan bijih besi), terdiri dari produk baja hulu (besi pelet/pig iron danbesi sponge) yang merupakan bahan baku bagi industri baja antara untuk diproses menjadi produk baja hilir atau produk akhir (Kementerian Perindustrian, 2016).

Industri baja antara menghasilkan 2 macam industri, pertama yang mengolah baja hulu (besi pelet danbesi spons) menjadi baja kasar/crude steel (bloom, billet, slab dan ingot).

1. Bloom merupakan bahan baku industri baja pengolahan long product (rel kereta, pelat baja, besi siku, dll).

2. Billet/baja batangan merupakan bahan baku untuk industri baja profil, baja tulang beton dan baja kawat. Billet/baja batangan memiliki ukuran penampang $1,0 \mathrm{~m} ; 1,1 \mathrm{~m}$, $1,2 \mathrm{~m}$ dan , 1,3m dan standar panjang 6,0 $\mathrm{m}, 10,0 \mathrm{~m}$, dan $12,0 \mathrm{~m}$.

3. Slab/baja lembaran merupakan bahan baku untuk pembuatan baja lembaran canai panas (hot rolled coil plate/HRC plate) dan baja lembaran dingin (cold rolled coil/CRC sheet). Slab/baja memiliki dimensi lebar $1,0 \mathrm{~m}$, tebal 20 $\mathrm{cm}$, panjang 6,0 $\mathrm{m}$ dan beratnya dapat mencapai 30 ton per buah. HRC adalah bahan baku industri pengolahan flat product (konstruksi, pipa las spiral dan lurus, komponen kapal, rangka otomotif, jalur pipa untuk migas, casing dan tubing pipa sumur minyak, tabung gas, baja tahan korosi, baja rerolling, konstruksi kapal, boiler dan pressrurized container, sedangkan CRC merupakan bahan baku industri peralatan rumah tangga, otomotif, pelapisan seng.
4. Ingot merupakan bahan baku industri baja lainnya.

Yang kedua, mengolah billet dan bloom menjadi baja semi (wire rod dan green pipe).

1. Wire rod merupakan bahan baku untuk industri pengolahan long finished product seperti paku, baut, mur, kawat las dan kawat baja high carbon ( $P C$ wire).

2. Green pipe merupakan bahan baku untuk industri seamless pipe untuk menghasilkan oil country tubular goods (OCTG) pipe dan Line Pipe pada industri pengeboran minyak, gas dan gheothermal.

Industri baja hilir, menghasilkan baja finished flat product yang merupakan bahan baku (industri konstruksi, otomotif, pipa, profil dan pelapisan) dan baja finished long product, merupakan bahan baku (industri pembuatan baja batangan, profil, baja konstruksi, kawat, paku dan mur/baut).

Berdasarkan data Direktorat Jenderal Mineral dan Batubara (2017), sampai tahun 2017, dari seluruh industri pengolahan dan pemurnian besi yang berjumlah 9 perusahaan seluruhnya berhenti beroperasi, karena tidak berjalannya rantai nilai dari industri logam besi. Seluruh perusahaan tersebut 7 yang dalam rencana, antara lain PT. Silo, PT. Sumber Baja Prima, PT. Megatop Inti Selaras, PT. Mikgro Metal Perdana, PT. Rusan Sejahtera, PT. Quantum Energi Perkasa, dan PT. Jogya Magasa Iron; demikian juga 2 industri yang sudah beroperasi dari tahun 2016, yaitu PT. Delta Prima Steel dan PT. Meratus Jaya Iron Steel.

Tidak berjalannya rantai nilai dari industri logam besi, disebabkan rangkaian kegiatan yang dilakukan perusahaan yang terdiri dari kegiatan utama dan kegiatan pendukung untuk menghasilkan produk/jasa yang bernilai tambah dari industri logam besi tidak berjalan (Porter, 1985), mulai dari hulu (proses tambang pasir besi dan bijih besi), hingga hilir (untuk memproses produk hulu menjadi bahan baku bagi industri baja), hingga produk hilir ini sampai ke konsumen akhir PT. Krakatau Steel, 2016 (Gambar 1). Demikian juga, aktivitas dalam rantai nilai yang terdiri dari sub-aktivitas (Kusumawati and Santosa, 2013). Misalnya, tahap pengembangan teknologi yang akan melibatkan aktivitas-aktivitas seperti penelitian dan pengembangan produk melalui berbagai 
macam percobaan, memproses produk, dan meningkatkan mutu produk terus-menerus juga masih tidak berjalan. Rantai nilai bijih besi ini (Nugraheni, 2014), adalah suatu bagian dari sistem yang lebih besar. Menurut (Sampit, Kindangen and Wullur. M., 2016), setiap perusahaan akan berinteraksi dengan para pemasok, distributor, dan pelanggan dan sistem yang diperluas ini akan membentuk rantai persediaan, sehingga apabila rantai nilai bijih besi ini tidak dapat berjalan, maka rantai nilai pesediaan pada industri besi dan baja akan kesulitan untuk mendapatkan bahan baku (Gambar 2).

Haryadi (2017) berpendapat, tidak berjalannya rantai nilai pada industri pengolahan dan pemurnian besi, akan menyebabkan peran industri pertambangan bijih besi dalam perekonomian dan penciptaan nilai tambah sangat rendah, karena tidak adanya peningkatan nilai tambah dari industri tersebut, dan industri hulu yang membutuhkan bahan baku besi olahan akan tergantung kepada bahan baku impor yang harganya mahal. Kalau rantai nilai bijih besi ini dapat berjalan, maka akan menghasilkan, logam besi yang merupakan bahan baku penting yang diperlukan hampir oleh seluruh industri dalam negeri, sebagai bahan dasar untuk konstruksi beton, bangunan, jembatan dan juga peralatan transportasi seperti kereta api, mobil, sepeda, motor, dan lain-lain, sehingga akan memberikan dampak yang positif dalam masalah penyediaan lapangan kerja yang tinggi, baik dalam masalah pendapatan maupun dalam hal kuantitas sumber daya manusia yang dibutuhkan (Yunianto, 2014).

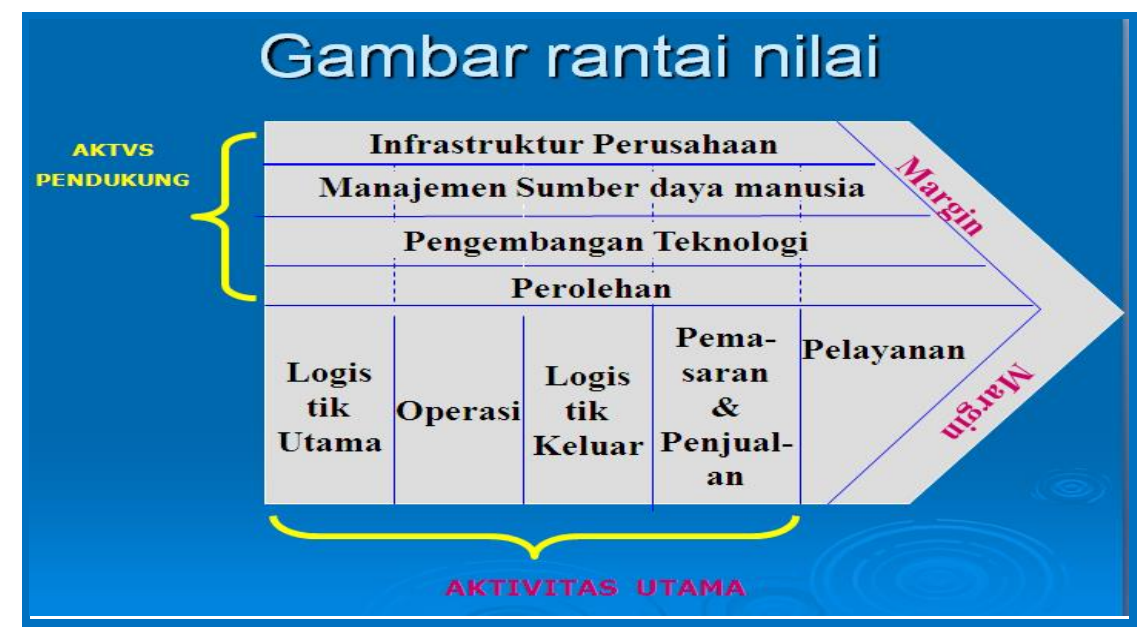

Gambar 1. Rantai nilai sebuah perusahaan (Porter, 1985)

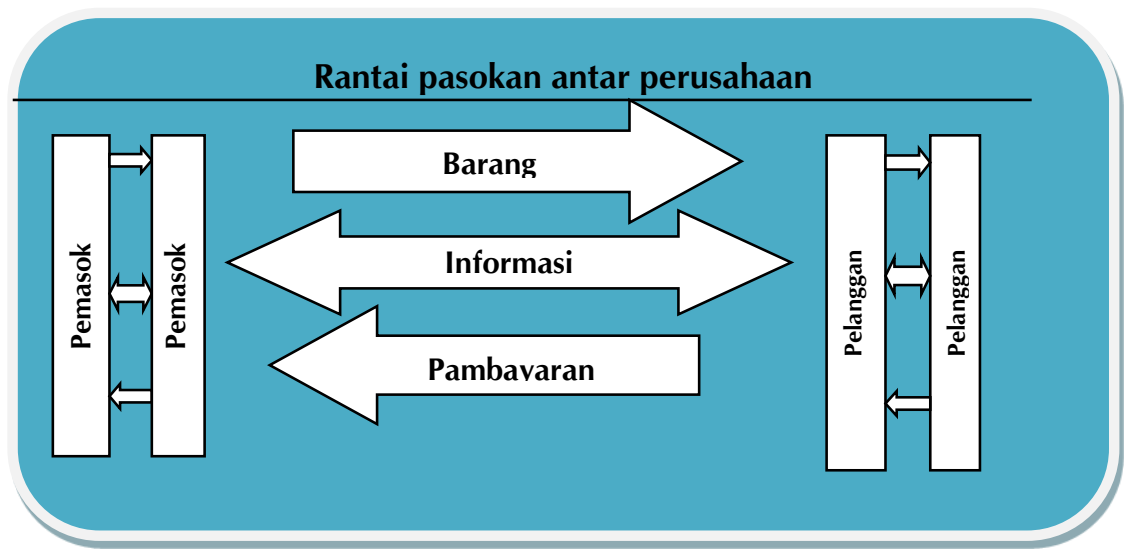

Gambar 2. Rantai persediaan (Sampit, Kindangen dan Wullur, 2016). 
Dari studi kasus terhadap dua perusahaan pengolahan dan pemurnian besi yang kesulitan beroperasi, yaitu PT. Delta Prima Steel dan PT. Meratus Jaya Iron Steel, terdapat 5 aktivitas primer dan 4 aktivitas sekunder dalam rantai nilainya yang lemah.

Lima aktivitas primer yang tidak berjalan tersebut, adalah :

1. Logistik masuk/logistik utama (inbound logistics). Perusahaan memiliki kelemahan aktivitas yang berhubungan dengan penanganan material sebelum digunakan berupa rangkaian kegiatan penerimaan/ penyimpanan/distribusi bahan baku (distribusi bahan baku bijih besi).

2. Manajemen Operasi/Operasi Produksi. Perusahaan memiliki kelemahan aktivitas yang dilakukan untuk mengubah input menjadi output/produk ke tangan konsumen/mengubah bahan baku menjadi produk (mengubah bijih besi menjadi pelet dan besi sponge atau logam besi).

3. Logistik keluar. Perusahaan memiliki kelemahan akivitas yang berhubungan dengan menyampaikan output ke konsumen (mengirimkan baja/pelet/besi sponge ke industri pengolah baja/industri mobil/motor/elektronik dan lain-lain).

4. Pemasaran dan Penjualan. Perusahaan memiliki kelemahan aktivitas yang berhubungan dengan pengarahan konsumen/membujuk agar tertarik untuk membeli produk (mempromosikan produk baja/pelet/besi spongenya ke industri pengguna dengan menginformasikan produknya berkualitas).

5. Pelayanan/Jasa Pemeliharaan. Perusahaan memiliki kelemahan aktivitas untuk mempertahankan atau meningkatkan nilai dari produk yang dapat memberi kepuasan kepada konsumen (peningkatan kualitas hasil produknya kepada pelanggan/ pelayanan atau penyempurnaan spesifikasi produk, bila ada yang tidak sesuai dengan keinginan industri penggunanya).

Adapun 4 aktivitas pendukung yang tidak berjalan, adalah :

1. Infrastruktur perusahaan/administrasi. Perusahaan memiliki kelemahan dalam rangkaian kegiatan yang terdiri dari departemen-departemen/fungsi-fungsi (akuntansi, keuangan, hukum, administrasi, perencanaan, dan sebagainya) yang melayani kebutuhan organisasi dan mengikat bagian-bagiannya menjadi sebuah kesatuan, sehingga perusahaan beroperasi tidak maksimal dan menghasilkan besi baja/besi pelet/besi sponge tidak sesuai spesifikasi yang dibutuhkan industri penggunanya sehingga kurang memiliki daya saing.

2. Manajemen sumber daya manusia (SDM). Dalam hal kegiatan berupapengaturan SDM mulai dari perekrutan/kompensasi/ pemberhentian/pelatihan/pengontrakan/p embagian deviden dari perusahaan pengolahan dan pemurnian industri baja/besi pelet/besi sponge kepada SDM masih kurang berjalan.

3. Teknologi. Dalam rangkaian kegiatan berupa kelitbangan (pengembangan peralatan, software, hardware, laman, disain produk, prosedur, transformasi produk dari input menjadi output untuk mengembangkan bijih besi menjadi baja/besi pelet/besi sponge masih lemah.

4. Pengadaan (procurement), yaitu rangkaian kegiatan yang berkaitan dengan proses pembelian/perolehan input/sumber daya/ bahan baku bijih besi masih tergantung kepada pemasok bahan baku dari perusahaan lain. Kedua perusahaan tersebut tidak memiliki tambang besi (IUP besi), sehingga kebutuhan bahan bakunya dipasok dari IUP yang berada di wilayah setempat atau dari luar wilayah sesuai dengan spesifikasi bijih besi yang diperlukan, sehingga jika terjadi kekurangan bahan baku cukup menyulitkan, karena tergantung kepada perusahaan lain. Selain itu, pengadministrasian perusahaan akan terganggu saat bahan baku sulit untuk diperoleh (Anam, 2014).

Sebelum 2014, PT. Delta Prima Steelmenghasilkan besi sponge 105.000 ton/tahun. Sedangkan PT. Meratus Jaya Iron Steel menghasilkan besi sponge 315.000 ton per tahun. Namun sejak Januari 2016, kedua perusahaan ini tidak melakukan kegiatan, karena sejak 2014 harga pasar produknya menurun sangat tajam. Menurut Baihaqi, Hamid, Romano, \& Yulianda (2014), dengan menurunnya harga pasar dan produk bijih besi, seharusnya perusahaan meningkatkan aktivitas primer berupa peningkatan penjualan dan promosi agar bisa 
meningkatkan penjualan. Kelemahan dalam penjualan dan promosi ini menyebabkan hasil produk tidak inovatif dan tidak kompetitif, serta penyediaan produk dan layanan produknya tidak berfungsi efektif.

Kelemahan dalam aktivitas sekunder berupa pengadaan, menurut Sipayung (2010), menjadi hambatan dalam pengadaan bahan baku yang dialami PT. Meratus Jaya Iron Steel. Selama ini, produksi bijih besi di Kalimantan Selatan belum mencukupi sebagai sumber bahan baku, apabila dikaitkan dengan spesifikasi (kebersihan, kimiawi, ukuran berhubungan dengan kesiapan pemasok); kontinuitas dan kuantitas pasokan bahan baku belum sesuai rencana; karakteristik bijih besi bervariasi, sehingga menyulitkan proses operasi (tercampur magnetit-hematit). Perusahaan ini juga menghadapi hambatan dalam masalah teknologi, sehingga produk dari bijih besi laterit tidak bisa diproses sebagai bahan baku baja komersial (kandungan $\mathrm{Ni}$ dan $\mathrm{Cr}$ tinggi) dan perusahaan tidak dapat menghasilkan produk olahan yang bermutu tinggi. Selain itu, perusahaan tidak dapat melakukan peningkatan inovasi dan modernisasi terhadap hasil produknya.

Berdasarkan informasi Direktorat Jenderal Mineral dan Batubara (2017), terhentinya rantai nilai industri logam besi, salah satu hambatannya dalam masalah Manajemen Sumber Daya Manusia, yaitu SDM kurang profesional, karena kurangnya unit-unit untuk melakukan pelatihan SDM, kurangnya penguasaan teknologi bagi SDM, kurangnya pengembangan teknologi informasi bagi SDM. Selain masalah SDM, masalah lainnya adalah minimnya infrastruktur perusahaan (administrasi), berupa kesulitan pembiayaan proyek pengolahan dan pemurnian akibat krisis global dan jatuhnya harga komoditas berbasis besi yang mengakibatkan menurunnya keekonomian proyek tersebut. Kondisi kesulitan finansial ini juga menyebabkan sistem informasi manajemen kurang handal. Selain itu, akuntansi, operasi, keuangan, pembentukan bagian SDM menjadi lemah dan perusahaan tidak dapat melakukan layanan penjualan secara modern dengan perangkat teknologi informasi.
Masalah lainnya yang dihadapi dalam pembangunan pengolahan dan pemurnian menurut Emhar, A., ulyo Aji, dan Agustin, (2014) adalah masalah kesulitan operasional, dalam pemeliharaan penggunaan seluruh aset perusahaan, menghasilkan produk sesuai standar internasional, dan sulit memantau penggunaan seluruh mesin-mesin pabrik. Dalam masalah logistik keluar, perusahaan juga mengalami kesulitan melaksanakan jalur distribusi yang seimbang antara jaringan pabrik, kantor cabang dengan kantor pusat secara konvensional dan hubungan dengan teknologi informasi. Selain itu, dalam masalah pelayanan, perusahaan sulit menghasilkan produk olahan yang spesifikasinya sesuai kebutuhan industri penggunanya, sulit menepati waktu permintaan dari industri penggunanya dan sulit menjaga keberlanjutan pasokan bagi industri penggunanya. Seluruh permasalahan rantai nilai yang dihadapi kedua perusahaan tersebut berupa aktivitas primer dan sekunder, berdampak berhentinya kedua perusahaan tersebut, dan menyebabkan rantai nilai kedua perusahaan ini tidak berjalan, sehingga mengganggu rantai pasokan industri bijih besi di Indonesia.

Menurut Apriliyanti (2014), apabila rantai nilai industri pengolahan dan pemurnian tidak berjalan dalam rantai persediaannya, suatu perusahaan bisa membantu dirinya sendiri dengan cara menolong perusahaan lain untuk memperbaiki kinerja mereka. Menurut Fauziah dan Ihwana (2015), apabila dalam rangkaian aktivitasnya perusahaan memiliki kesulitan, perusahaan dapat memperbaiki aktivitas pembelian dan logistik keluar dengan mengimplementasikan sistem manajemen (tepat waktu). Biaya perusahaan berkurang, karena aktivitas pembelian dan logistik keluar dilakukan dengan lebih efisien, karena jumlah modal perusahaan yang terikat untuk persediaan jadi berkurang,sehingga menurut Mangifera (2015), perusahaan dapat memperoleh keuntungan tambahan apabila mereka menghubungkan sistem baru mereka dengan para pemasok untuk membantu mereka melaksanakan beberapa aktivitas utama dengan lebih efektif dan efisien. Menurut Setiawati (2014), dengan memberikan informasi yang lebih rinci dan tepat waktu tentang kebutuhan persediaannya, perusahaan dapat membantu para pemasok 
untuk merencanakan secara lebih efisien jadwal produksinya agar sesuai dengan kebutuhan perusahaan. Apabila perusahaan membantu perusahaan terkait dalam rantai persediaan, maka perusahaan mengurangi biaya yang ditanggung para pemasok, dan sebagian dari pengurangan biaya itu akan memberi keuntungan bagi perusahaan, yaitu dalam bentuk biaya produk yang lebih rendah (Irawan and Suryaloga, 2009).

\section{KESIMPULAN DAN SARAN}

\section{Kesimpulan}

Sampai 2017, rantai nilai industri pasir besi dan bijih besi pada industri pengolahan dan pemurnian besi Indonesia tidak berjalan, menandakan terputusnya rantai nilai pada industri ini. Tidak berjalannya rantai nilai industri pasir besi dan bijih besi ditandai dengan berhentinya beroperasi hampir seluruh industri tersebut dari yang sudah direncanakan 9 perusahaan dan hampir semuanya tidak melakukan kegiatan operasi. Terputusnya rantai nilai industri besi di Indonesia disebabkan banyaknya aktivitas primer dan sekunder yang tidak bisa dijalankan oleh perusahaan yang akan membangun industri pengolahan pasir besi dan bijih besi. Dengan terputusnya rantai nilai industri besi ini, menyebabkan, industri domestik yang membutuhkan olahan bijih besi sangat tergantung kepada pasokan impor sehingga produknya tidak kompetitif, devisa negara hilang, kesempatan kerja berkurang, pengaruh positifnya terhadap perekonomian nasional tidak signifikan karena perolehan ekonominya rendah, tingkat daya saing industri domestik rendah karena ongkos produksi mahal, dan perusahaan tambang pengolahan dan pemurnian bijih besi banyak yang mengalami kerugian besar dari investasi yang sudah ditanamkan.

\section{Saran}

1. Aktivitas-aktivitas yang mempunyai nilai tinggi (aktivitas operasi dalam aktivitas primer) dan (peningkatan Sumber Daya Manusia pada aktivitas sekunder) mempunyai potensi untuk dikembangkan, sehingga menjadi keunggulan bagi perusahaan untuk menghasilkan produk jadi yang dapat bermanfaat, khususnya bagi industri domestik yang membutuhkan bahan baku olahan industri bijih besi.

2. Agar mata rantai industri bijih besi dapat berjalan dan perusahaan dapat membangun pabrik pengolahan dan pemurnian pasir besi dan bijih besi, sehingga dapat memasok industri domestik, maka diperlukan dukungan dari semua pemangku kepentingan, untuk membantu aktivitas primer perusahaan, antara lain penyediaan infrastruktur yang mendukung, yang merupakan tingkat kepentingan yang paling utama (dengan skor 0,615). Dukungan logistik ke dalam yang memiliki tingkat kepentingan yang utama setelah infrastruktur dengan skor 0,461 (menyediakan bahan baku yang cukup bagi industri pengolahan bijih besi. Dukungan logistik ke luar, yang memiliki skor 0,307 (membantu untuk mempermudah jalur distribusi penjualan produk dari industri pengolahan bijih besi. Selain itu, dukungan dari pemangku kepentingan adalah ikut membantu dalam masalah penjualan dan promosi produk pengolahan bijih besi dan membantu agar perusahaan dapat menghasilkan produk yang sesuai dengan spesifikasi yang diinginkan industri penggunanya.

3. Dukungan dalam masalah aktivitas sekunder, antara lain dukungan masalah kemudahan bantuan pinjaman dari perbankan, menyediakan pusat-pusat pelatihan untuk menciptakan sumber daya manusia yang handal, bantuan dalam masalah penggunaan teknologi yang tepat guna, dan bantuan dalam masalah penyediaan bahan baku yang cukup untuk industri pengolahan bijih besi.

\section{UCAPAN TERIMAKASIH}

Penulis mengucapkan terimakasih kepada kontributor yang telah membantu memberikan data yang terkait dengan penelitian ini, antara lain Pusat Sumber Daya Geologi, Direktorat Jenderal Mineral dan Batubara, dan Kementerian Perindustrian. Disamping itu, penulis juga mengucapkan terimakasih kepada PT. Delta Prima Steel dan PT. Meratus Jaya Iron Steel atas bantuan data yang terkait dengan penelitian ini. Semoga 
Allah swt membalas kebaikannya dengan rahmat dan keberkahan yang lebih besar.

\section{DAFTAR PUSTAKA}

Anam, K. (2014) Analisis rantai nilai susu kambing di UD Harokah Barokah Bogor. Universitas Islam Negeri Syarif Hidayatullah. Available at:

http://repository.uinjkt.ac.id/dspace/bitstream /123456789/28949/1/KHOIRUL ANAMFST.pdf.

Andri, K. B. (2013) "Analisis rantai pasok dan rantai nilai bunga krisan di daerah sentra pengembangan Jawa Timur," SEPA, vol.10(1), pp. 1-10.

Apriliyanti, T. (2014) Analisis rantai nilai (value chain) tahu kuning di sentra industri tahu, Kecamatan Adiwerna, Kabupaten Tegal. Universitas Diponogoro.

Baihaqi, A., Hamid, A. ., Romano and Yulianda, A. (2014) "Analisis rantai dan nilai tambah kakao petani di Kecamatan Paya Bakong dan Geurudong Pase Kabupaten Aceh Utara," argisep, Vol. 15(No. 2), pp. 28-35.

Direktorat Jenderal Mineral dan Batubara (2017) Laporan Kinerja (LAKIN) 2016. Jakarta.

Emhar, A., M., ulyo Aji, J. M. and Agustin, T. (2014) "Analisis rantai pasokan (supply chain) daging sapi di Kabupaten Jember," Jurnal Berkala Ilmiah Pertanian, Fakultas Pertanian Universitas Jember, 1(3), pp. 5361.

Fauziah, U. and Ihwana, A. (2015) "Analisa rantai nilai distribusi kopi di Kabupaten Garut," Kalibrasi, 1(13), pp. 1-8.

Haryadi, H. (2017) "Analisis neraca sumber daya pasir besi dan bijih nikel Indonesia," Jurnal Teknologi Mineral dan Batubara, 13(2), pp. 153-169. doi: 10.30556/jtmb.Vol13.No2.2017.171.

Irawan, H. and Suryaloga, R. (2009) "Analisis rantai nilai industri tekstil dan produk tekstil (TPT) di Indonesia," Jurnal Manajemen Indonesia, 9(3), pp. 19-27.

Kementerian Perindustrian (2016) "Rencana Induk Pembangunan Industri Nasional, 20152035." Pusat Komunikasi Publik Kementerian Perindustrian, p. $51 \mathrm{~h}$.
Kusumawati, A. and Santosa, P. B. (2013) "Rantai nilai(value chain) agribisnis labu di Kecamatan Getasan Kabupaten Semarang," Diponogoro Journal of Economics, 2(4), pp. 1-10.

Mangifera, L. (2015) "Analisis rantai nilai (value chain) pada produk batik tulis di Surakarta," Benefit Jurnal Manajemen Bisnis, 19(1), pp. 24-33.

Nugraheni, P. I. (2014) Analisis rantai nilai komoditas pertanian ubi kayu (Manihot sculeta Crantz) di Kecamatan Tlogowungu, Kabupaten Pati. Universitas Diponogoro. Available http://eprints.undip.ac.id/45366/.

Parlinah, N., S., I., Prawesti Suka, A. and Kirsfianti, L. G. (2015) "Distribusi nilai tambah dalam rantai nilai kayu sengon (Paraserianthes falcataria) dari Kabupaten Pati, Jawa Tengah, Indonesia," Jurnal Penelitian Sosial dan Ekonomi Kehutanan, 12(2), pp. 77-87.

Permana, D. (2010) “Dampak penerapan UndangUndang Nomor4 Tahun 2009 terhadap pengembangan usaha pertambangan mineral dan batubara," Jurnal Teknologi Mineral dan Batubara, 6(4), pp. 165-173.

Porter, M. (1985) "Competitive advantage: Creating and sustaining superior performance, with a new introduction." New york.

PT. Krakatau Steel (2016) Laporan tahunan (annual report) 2016: Creating a better future with times. Available at: http://www.krakatausteel.com/pdf/AR KS 2016 Final LR.pdf.

Pusat Sumber Daya Geologi (2016) Laporan akhir pemutakhiran data dan neraca sumber daya mineral. Bandung.

Sampit, M., Kindangen, P. and Wullur. M. (2016) "Analisis rantai nilai gula aren (Studi kasus pada petani nira di Tomohon)," Jurnal EMBA, 4(5), pp. 303-313.

Setiawati, N. (2014) Analisis rantai nilai cabai di sentra produksi Kabupaten Majalengka, Jawa Barat. Institut Pertanian Bogor.

Sipayung, F. (2010) "Value chain analysis (analisis rantai nilai) untuk keunggulan kompetitif melalui keunggulan biaya," Jurnal Ekonom, 13(1), pp. 36-44. Available at: http://repository.usu.ac.id/handle/123456789 143510. 
Analisis Bobot dan Peringkat Porter untuk Mengetahui Aktivitas yang Paling ... Endang Mulyani dan Harta Haryadi

Yunianto, B. (2014) "Analisis dampak kebijakan nilai tambah mineral Indonesia terhadap ekspor dan ketenagakerjaan," Jurnal Teknologi Mineral dan Batubara, 10(3), pp.
127-141. Available at: http://jurnal.tekmira.esdm.go.id/index.php/m inerba/article/view/729. 
